\title{
Predicting Financial Solvency of Commercial Borrowers: The Case of Non-Banking Financial Companies
}

\author{
Sunita Mall ${ }^{1}$, Tushar R. Panigrahi ${ }^{2} \&$ Stephina Thomas $^{3}$ \\ ${ }^{1}$ MICA-The School of ideas, Ahmedabad, India \\ 2 ITM Business School, Mumbai, India \\ ${ }^{3}$ SS\&C Globeop Financial Services India Pvt.Ltd \\ Correspondence: Sunita Mall, MICA-The School of ideas, Ahmedabad, India. E-mail: sunita.mall@ micamail.in
}

Received: July 26, 2018

Accepted: May 28, 2019

Online Published: July 2, 2019

doi:10.5430/afr.v8n3p61

URL: https://doi.org/10.5430/afr.v8n3p61

\begin{abstract}
Credit risk can be effectively managed by evaluating and predicting the credit worthiness of a customer or a corporate. Credit scores are calculated to assess the credit worthiness. It helps the financial institutes to know the amount and dimensions of risk involved in different credit transactions. Credit scoring helps the financial institutes to decide whether or not to lend. It also helps in deciding the price of a particular exposure, the appropriate credit facility and different risk tools. This research paper focuses on identifying the triggers of credit default. It also focuses on checking and predicting the financial solvency of the borrowers of non-banking financial companies and assigning the credit worthiness to these companies. The data is collected from a Mumbai based NBFC. The data for the study are extracted from balance sheet and profit \&loss statement of these companies. The data includes the financial ratio variables for forty companies. Altman's Z-score is used to find credit worthiness and DuPont technique is used to find the main causes of financial distress. The results of this research highlights that the borrowing companies having a lower return on equity (ROE) are prone to be in distress zone. This research would help the financial institutions to identify the most likely defaulter companies and to segment the clients/companies in safe, grey and distressed zones. The results are robust to sub-samples.
\end{abstract}

Keywords: financial distress, grey zone, safe zone, DuPont, financial ratio, Altman Z-score

JEL Classification: G23, G33, C22, C45, C10

\section{Introduction}

Credit worthiness of a customer or client is measured using his/her credit risk score. The amount and dimension of risk involved in different credit transactions can be known through credit scoring. Credit scoring helps the financial institutions in various operational and strategic decisions such as whether to lend or not, deciding pricing of a particular exposure, determining the appropriate credit facility, identifying different risk tools etc. It also emphasizes the depth and frequency of review and the necessary precautions to be taken for the same.

Non-Banking financial companies (NBFCs) are the group of institutions, which performs the financial intermediation in different ways like making loans, leasing, accepting deposits etc. They lend the funds to the customer(s)/client(s), which they collect from the public directly or indirectly. They give loans to the small-scale industries, retailers, wholesalers and to the self-employed persons. Thus, they offer multiple products and services. They are recognized due to their customers/clients oriented services, simplified procedure, attractive and high rate of return and flexibility procedure.

Non-Banking financial companies are registered with Reserve Bank of India. Sec 45-IC of the RBI defines "financial institution". A nonbanking company carrying business of financial institution will be an NBFC. Activities included in the definition: Financing, whether by giving loans, advances or otherwise acquisition of shares, stocks or securities, hire purchase Insurance - excluded by notification management of chits, money circulation schemes. (Note 1)

Altman (1968) classified the observations based on their characteristics into two groups. Working capital, retained earnings, market capitalization, earnings before interest and taxes are the financial ratios considered in this research. He performed multivariate discriminant analysis for classification. Good and bad credits are classified using a credit-scoring model. (Lee et al, 2002). To predict the corporate failure Altman (1968) calculated twenty-two 
financial ratios, which is used in Z-score model. This research paper focuses on building a risk assessment model to rate risk associated with the credit exposure on a probability scale and consequently to map these probabilities with the score bands for NBFC clients. The focus of this research is to check the financial solvency of the commercial borrowers using Altman's Z score model and to predict the credit worthiness of the borrower companies for next two years.

In general, NBFCs' lend credits to small and medium scale enterprises at a high risk. These enterprises are also categorized as assets with high risk. This research paper also attempted to assess the financial distress of the firms and to explore the determinants of financial distress of those firms. It also focuses on the determinants of credit default.

The data is collected from a Mumbai based NBFC. The balance sheet and profit \&loss statement of the companies are the sources from which the data is extracted. The data includes the financial ratio variables for forty companies who are the clients of that NBFC for a period of 2015-16 to 2017-18. The Mumbai based NBFC had given loan to 218 firms under manufacturing, non-manufacturing and service sector. All the borrower firms come under the category of small and medium scale enterprises. On an average, the NBFC has given loan to 147 non-manufacturing firms. In this research forty randomly selected non-manufacturing firms are considered. The borrower companies name is not disclosed in this research paper due to the confidential issues and due to the request of the data provider. However, the forty borrower companies are labeled as $\mathrm{M}_{1}$ to $\mathrm{M}_{40}$.

The financial ratios such as working capital/total asset, retained earnings/total asset, earnings before interest \&tax/total asset, market value of equity/total assets, market value of equity/total liabilities, tax burden, interest burden, operating income margin, asset turnover, equity multiplier are the explanatory variables considered for predicting the financial distress of the companies. For this purpose, Altman's Z score and DuPont technique is used.

The results of this research depicts that those borrowing companies are expected to be in distress zone whose return on equity (ROE) is lower. In case of the two companies, namely, ' $\mathrm{M}_{11}$ ' and ' $\mathrm{M}_{9}$ ' it is seen that both the company's asset turnover ratio is very low which shows the asset utilization efficiency is very low and the management needs to take care of this business problem. Particularly the revenue generation is very low which may be due to poor marketing and promotion of the product or may be due to the product's poor quality, which did not attract the customer to spend on it. Interest burden in case of company ' $\mathrm{M}_{11}$ ' is initially very high because the debt component is at a higher side and thus the operating income margin reduces year on year bringing down the ROE as a whole.

Some of the existing literature focuses on the company and business characteristics such as business or corporate loans, financial ratios, credit amount, bank loans, profitability, leverage etc for credit scoring models whereas the other set of literature focuses on assessment of the new as well as existing customers who were granted loans. This research paper focuses on predicting the financial solvency of the commercial borrowers and assessing the financial distress of the firms.

This study highlights the following concerns and addresses the concerns through empirical statistical analysis:

a) Checking the financial solvency of the borrowers' companies

b) To ascertain the credit worthiness of the borrower companies for the next two years.

c) Assessing the financial distress of the firms

d) Finding out the determinants of credit default.

In this research paper section 2 deals with literature review, research objective is discussed in section 3 and in section 4 the methodology is explained. The statistical analysis along with interpretation is explained in section 5 . Section 6 deals with summary and conclusion and section 7 focuses on the implication of the research.

\section{Existing Literature}

The existing research on credit risk modeling is discussed in this section of the research paper. A credit score can be defined as a numeric expression of a customer's creditworthiness. To estimate the likelihood of a customer to be defaulter, the financial institutions use credit scores. History along with other socio-economic characteristics of a people define his/her credit worthiness. A person is assumed to be more creditworthy if the credit score of that person is high. Edward I. Altman (Altman, 1968) first published the widely popular Z-score function used for analyzing and predicting bankruptcies in 1968.

Altman's conducted the research on sixty-six corporations with thirty-three companies in each group which are considered for the time period of 1946 to 1965 . The Z-score was calculated using multiple inputs from corporate 
income statements and balance sheets. The Z-score is used to measure the financial status of a company. Altman selected the inputs from those financial reports that are one reporting period earlier than bankruptcies. The inputs that Altman used were twenty-two different financial ratios. Altman considered those financial ratios, which were chosen to eliminate size effects. Those ratios were divided in five standard financial categories: liquidity, profitability, leverage, solvency, and activity. He performed linear multiple discriminant analysis (MDA) to find the best combination of five variables from an original set of variables.

The main objective of credit scoring models is to sanction loan to the customers to either good credit or bad credit. (Lee et al, 2002). Altman (1968) used MDA to evaluate a set of ratios for two possible outcomes say; failure and survival. In developing the Z-Score, Altman (1968) calculated 22 financial ratios, which were thought to be useful in the context of predicting corporate failure based on previous studies (Altman, 2000). These 22 financial ratios are classified in five different categories as liquidity, profitability, leverage, solvency and activity (Altman, 2000). Using multiple discriminant analysis (MDA) the five most significant contributors to corporate failure were then determined.

Lyn C Thomas (2000) studied the credit and behavioral scoring to forecast the financial risk to lend to customers. He used both statistical and operational research based techniques. He highlighted that the economic conditions should be introduced into the scoring system. The two major developments he focused on are to estimate the likelihood of a default consumer and to estimate profit that a consumer can contribute to the lending organization.

M.N Kumar \& V. Sree Hari Rao (2014) developed a new methodology to estimate internal credit risk and to predict bankruptcy. Altman's z-score has been used to study credit estimation and bankruptcy prediction. Multivariate non-linear model is used in their study for computing z score. They develop a new credit risk index for which they fit a Pearson type 3 distribution to the financial ratios that are transformed. They found that their index could predict bankruptcy with an accuracy of $98.6 \%$, which is found to have better prediction power than that of Altman's Z-score model with an accuracy of $93.5 \%$. The results of discriminant analysis depicts that the transformed financial ratios could predict bankruptcy with more accuracy than that of Altman's Z-score.

Suleyman Basak \& Alex Shapiro (2004) developed a model of credit risk, optimal policies and asset prices. They found that borrowers who are defaulting under adverse economic conditions emerge as wealthier than non-borrowers' despite of the default cost. Key Giesecke(2004) estimated the joint default probabilities and prices of credit sensitive securities by reviewing the structural, reduced form and incomplete approaches.

Srinivas Gumparthi, swetha Khatri \& V.Manickavasagam (2011) used discriminant analysis to clarify into two or more groups based on knowledge of some variables related to them. They also proposed weighted average method, which can be used for predicting the credit worthiness of the clients.

Bardos (1998) presents the quantitative framework of credit risk model in which the optimum frontier between failed and non-failed companies, which is defined as a linear function of some financial ratios, is being explained by the principle of MDA. Engelmann et al (2003) remarked that different rating models can be validated by means of ROC and CAP only on the same data set. He reviewed two-validation techniques say, Cumulative Accuracy Profile (CAP) and Receiver Operator Characteristic (ROC). To build credit score models, the factors like loan amount, loan duration, bank accounts, having a car, mortgage guarantees etc have been used by many researchers. (Lee\& Chen, 2005; Ong et al,2005; Sarlija et al, 2004; Greene 1998; Steenacker and Goovarts 1989)

Most of the researchers have also used the company and business characteristics like business or corporate loans, financial ratios, credit amount, bank loans, profitability, leverage etc for building credit scoring models. (Min and Jeong,2009; Min \&Lee, 2008; Lensberg et al 2006; Bensic et al.2005; Zekic-Susac et al, 2004; Emel et al. 2003)

Mall,S. (2018) developed and validated a model to assess the risk associated with the credit exposure on a probability scale. The probability scale was used to map to score bands for NBFC customers. The objective was also to predict the future default behavior of the NBFC customers using credit scores. Logistics regression, decision tree and neural network models are developed and compared to find the best fit. Various fit statistics are used to validate the models. To check the credit worthiness of each of the customers the scorecard was used.

The selection of the variables based on the nature of the data. Sometimes, the selection depends on what cultural or economic variables may affect the model and be appropriate to a particular market. The existing literature on credit risk scoring is very thickly documented and due to different sample size, different explanatory variables, the results of such researches are not comparable. However, all explanatory variables show their importance in explaining the credit score model. 
Credit risk scoring is an important tool for credit risk management. It helps the financial institutes to know the amount and dimensions of risk involved in different credit transactions. Credit scoring helps the financial institutes to decide whether to lend, the pricing of a particular exposure, deciding the appropriate credit facility and different risk tools. It also helps the financial institutions authority in deciding the frequency and depth of review and precautions to be taken for the same.

This research paper focuses on building a risk assessment model to rate risk associated with the credit exposure on a probability scale and consequently to map probability to score bands for NBFC clients.

\section{Methodology}

\subsection{Data}

The main objective of this research paper includes determining the creditworthiness of the clients by using proposed statistical techniques. Secondary data is collected from a Mumbai based NBFC. The data source employed in our analysis is the clients who opted for loan and are the clients of NBFC. The name of the NBFC is not disclosed due to confidentiality. The balance sheet and profit \&loss statement of the borrower companies are used for data extraction. The data includes the financial ratio variables for forty companies who are the clients of that NBFC for a period of 2015-16 to 2017-18. The Mumbai based NBFC had given loan to 218 firms under manufacturing, non-manufacturing and service sector out of which 147 are non-manufacturing firms. In this research paper, 40 randomly selected non-manufacturing firms are considered.

\subsection{Explanatory Variables}

Few of the existing literature focuses on studying credit risk worthiness. These researchers have calculated the credit worthiness using the financial ratios of a financial institution. Some other focus only on the customers' demographic variables. Product or loan related variables are also used by some of the researchers to develop the credit risk model. For this research work, the explanatory variables are considered based on the financial ratios of an NBFC. Working capital/total asset, retained earnings/total asset, earnings before interest \&Tax/total asset, market value of equity/total assets, market value of equity/total liabilities, tax burden, interest burden, operating income margin, asset turnover, equity multiplier are the financial ratio variables considered for predicting the financial distress of the borrower companies. Altman's Z-score technique and Du pont technique is used to answer the objectives of this research.

\subsection{Theoretical Framework}

Edward I. Altman (1968) has devised the Z-score formula for predicting bankruptcy. The model predicts whether a firm will go into bankruptcy within two years. Initially the model was developed on a dataset of publicly held manufacturers, which takes one of the five ratios, that is the ratio of market value of equity to the total liabilities. A lower score reflects higher odds of bankruptcy where as a score above 2.99 shows that at least in the next two years the firm is financially sound to meet the debt obligations. The banking industries as they finance to their corporate borrowers are keen to predict the financial insolvency as it can help them to reduce the non-performing assets and increase the profitability and liquidity.

The $\mathrm{Z}$ - score model developed by Altman is based on multiple discriminant analysis (MDA). MDA is preferred over the regression where the dependent variable is qualitative. The MDA technique considers a complete profile of characteristics, which are common to the firms under study. MDA finds the resultant Z-Score is a linear combination of five common business ratios. The coefficients of these ratios were estimated by spotting a set of firms, which had been declared as bankrupt. Then a matched sample of firms were found for the surviving firms. Thus, the original model as developed by Altman in 1968 is as follows:

$\mathrm{Z}$-Score $=1.2 \mathrm{X}_{1}+1.4 \mathrm{X}_{2}+3.3 \mathrm{X}_{3}+0.6 \mathrm{X}_{4}+1.0 \mathrm{X}_{5}$

Where $\mathrm{X}_{1}=$ Working Capital/Total Assets

$\mathrm{X}_{2}=$ Retained Earnings/Total Assets

$\mathrm{X}_{3}=$ Earnings before Interest $\&$ Tax/Total Assets

$\mathrm{X}_{4}=$ Market Value of Equity/Book Value of Liabilities

$\mathrm{X}_{5}=$ Sales/Total Assets

$\mathrm{Z}=$ overall index.

The cut off for this model is as follows: 


\begin{tabular}{|l|l|}
\hline$Z$ Score & Financial Status of the Borrowing company is in \\
\hline$Z<1.81$ & Distress Zone \\
\hline$Z>2.99$ & Safe Zone \\
\hline $1.81<Z<2.99$ & Grey Zone \\
\hline
\end{tabular}

The DuPont analysis is a method of performance measurement coined by the DuPont Corporation in the 1920s. To produce higher return on equity (ROE) in this method the assets are measured at their gross book value than that of net book value. DuPont analysis tells us that ROE is affected by three things i) operating efficiency, ii) asset use efficiency, iii) financial leverage.

ROE $=($ Net Profit Margin) $\mathrm{x}$ (Asset Turnover) $\mathrm{x}$ (Equity Multiplier)

Where:

Net Profit Margin = Net Income/Sales

Asset Turnover $=$ Sales $/$ Total Assets

Equity Multiplier $=$ Total Assets/Shareholders Equity

ROE $=($ Net Income/Sales $) \times($ Sales/Total Assets $) \times($ Total Assets/Shareholders Equity $)$

ROE is segmented into three parts. If ROE has increased due to an increase in net margin or asset turnover, it is a very good sign. On the contrary, if equity multiplier is causing a change in ROE, then it should be under review. The Five-Steps DuPont identity is an expansion over the Three-Steps DuPont identity that breaks down return on equity (ROE) into five parts: Tax Burden, Interest Burden, Operating profit margin, total asset turnover and financial advantage. The model has the added benefit to tell how interest payments on debt affects net profit margin.

To know the fundamentals of being defaulter once they are in distress zone that signifies the odds of default is very high as per Altman's Z-Score model. To find out the reasons of the changes in the credit worthiness, we used the DuPont technique, which will give a five-step break of the financial performance of the company.

\section{Empirical Findings and Analysis}

The empirical findings of the financial distress calculation using Altman's Z-scores model is discussed in this section. In section 5.1, the results of Altman's z score model is discussed. Du point technique is used to find the elements of financial distress of the borrower companies. The results of Du point analysis is discussed in section 5.2.

\subsection{Results Altman's Z-Score}

The study highlights a hypothesis that the NBFC had approved the loan to the financially sound companies who will not be defaulter in future. Thus the null hypothesis states that all the borrower companies selected through sampling are performing well to be announced as safe from credit default. The Z-score developed by Altman says if a borrowing company which is a private non manufacturing company gets a score of 2.9 or more is financially safe from credit default.

Hence, The null hypothesis is defined as :

$\mathrm{H}_{0}$ : The sample mean of the $\mathrm{Z}$ score of borrower companies is greater than 2.9.

$\mathrm{H}_{1}$ : The sample mean of the $\mathrm{Z}$ score of borrower companies is not greater than 2.9.

To develop Altman's Z-score, multiple discriminant analysis is used.Five financial ratios are calculated using the company's annual report. Edward I. Altman (1968) has devised the Z-score formula, which is used for predicting bankruptcy in our study. This model enables in predicting the bankruptcy status of a company within two years.

The model was initially developed on a dataset of publicly held manufacturers, which takes one of the five ratios, that is the ratio of market value of equity to the total liabilities. However, in case of private manufacturing, non-manufacturing and service companies, it is difficult to get the market value of equity because the private firms have not gone for public issues. As an extension, the original model has been redeveloped to suit the private manufacturing, non-manufacturing and service companies and so the loading factors for all the five ratios differ based on the type of the firm. The new model suggested by Altman (1983) calculates the odds of financial distress of private non-manufacturing companies. This model provides a new Z-score value that fits for private non-manufacturing or service companies, which is used in this research paper. The function and the buckets are as follows: 
Z-Score $=6.65 X_{1}+3.26 X_{2}+6.72 X_{3}+1.05 X_{4}+3.25$

Where $\mathrm{X}_{1}=$ Working Capital/Total Assets

$\mathrm{X}_{2}=$ Retained Earnings/Total Assets

$\mathrm{X}_{3}=$ Earnings before Interest \& Tax/Total Assets

$\mathrm{X}_{4}=$ Book Value of Equity/Book Value of Liabilities

\begin{tabular}{|l|l|}
\hline$Z$ Score & Financial Status of the Borrowing company is in \\
\hline$Z<1.23$ & Distress Zone \\
\hline$Z>2.9$ & Safe Zone \\
\hline $1.23<Z<2.9$ & Grey Zone \\
\hline
\end{tabular}

The model finds that if the $\mathrm{Z}$ score of a company is above 2.99 , the company would be safe for next two years and there is less likelihood of credit default. On the contrary, if the score is below 1.23 then the company has a significant chance of defaulting the debt repayment and within the next two years, it could be announced as insolvent.

The Mumbai based NBFC had given loan to 218 firms under manufacturing, non-manufacturing and service sector. All the borrower firms come under the category of small and medium scale enterprises. On an average, the NBFC has given loan to 147 non-manufacturing firms. For this research paper, 40 firms are randomly chosen. The names of the companies are not disclosed on the request of the NBFC. Altman's Z-score model is used to predict the financial distress of the companies. Company wise $\mathrm{Z}$-scores is given in table -1 as follows:

Table 1. Z-Score of Forty Debtor Firms from 2015-16 to 2017 -18.

\begin{tabular}{lllllllll}
\hline Company & $\mathbf{2 0 1 5}$ & $-\mathbf{2 0 1 6}$ & $-\mathbf{2 0 1 7}$ & - Company & $\mathbf{2 0 1 5}$ & - 2016 & 2017 & - \\
Name & $\mathbf{2 0 1 6}$ & $\mathbf{2 0 1 7}$ & $\mathbf{2 0 1 8}$ & Name & $\mathbf{2 0 1 6}$ & $\mathbf{2 0 1 7}$ & $\mathbf{2 0 1 8}$ \\
\hline $\mathbf{M}_{\mathbf{1}}$ & 0.559 & 0.594 & 2.687 & $\mathbf{M}_{\mathbf{2 1}}$ & 9.149 & 11.464 & 5.325 \\
$\mathbf{M}_{\mathbf{2}}$ & 5.845 & -0.148 & 3.241 & $\mathbf{M}_{\mathbf{2 2}}$ & 6.421 & 5.322 & 5.966 \\
$\mathbf{M}_{\mathbf{3}}$ & 12.299 & 5.557 & 5.554 & $\mathbf{M}_{\mathbf{2 3}}$ & 4.755 & 8.681 & 7.811 \\
$\mathbf{M}_{\mathbf{4}}$ & 6.482 & 8.435 & 7.734 & $\mathbf{M}_{\mathbf{2 4}}$ & 8.874 & 6.409 & 7.006 \\
$\mathbf{M}_{\mathbf{5}}$ & 21.595 & 18.865 & 15.183 & $\mathbf{M}_{\mathbf{2 5}}$ & 10.036 & 7.766 & 9.644 \\
$\mathbf{M}_{\mathbf{6}}$ & 7.99 & 9.249 & 8.04 & $\mathbf{M}_{\mathbf{2 6}}$ & 4.34 & 3.379 & 3.293 \\
$\mathbf{M}_{\mathbf{7}}$ & 7.213 & 6.832 & 9.443 & $\mathbf{M}_{\mathbf{2 7}}$ & 3.381 & 3.476 & 4.363 \\
$\mathbf{M}_{\mathbf{8}}$ & 3.258 & 4.965 & 4.884 & $\mathbf{M}_{\mathbf{2 8}}$ & 4.478 & 5.593 & 5.026 \\
$\mathbf{M}_{\mathbf{9}}$ & 2.851 & 3.206 & -1.334 & $\mathbf{M}_{\mathbf{2 9}}$ & 8.868 & 7.95 & 11.524 \\
$\mathbf{M}_{\mathbf{1 0}}$ & 0.77 & 4.884 & 4.463 & $\mathbf{M}_{\mathbf{3 0}}$ & 5.326 & 5.544 & 5.018 \\
$\mathbf{M}_{\mathbf{1 1}}$ & 1.823 & 0.119 & -0.847 & $\mathbf{M}_{\mathbf{3 1}}$ & 10.463 & 22.871 & 11.063 \\
$\mathbf{M}_{\mathbf{1 2}}$ & 0.428 & 0.8 & 0.701 & $\mathbf{M}_{\mathbf{3 2}}$ & 2.7 & 2.108 & 2.017 \\
$\mathbf{M}_{\mathbf{1 3}}$ & -0.33 & 0.327 & 0.244 & $\mathbf{M}_{\mathbf{3 3}}$ & 2.755 & 2.054 & 2.798 \\
$\mathbf{M}_{\mathbf{1 4}}$ & 2.312 & 2.602 & 2.258 & $\mathbf{M}_{\mathbf{3 4}}$ & 3.606 & 4.79 & 3.128 \\
$\mathbf{M}_{\mathbf{1 5}}$ & 17.559 & 5.293 & -3.734 & $\mathbf{M}_{\mathbf{3 5}}$ & 37.348 & 13.155 & 5.887 \\
$\mathbf{M}_{\mathbf{1 6}}$ & 7.646 & 9.168 & 10.095 & $\mathbf{M}_{\mathbf{3 6}}$ & 22.182 & 21.74 & 5.773 \\
$\mathbf{M}_{\mathbf{1 7}}$ & 6.403 & 6.238 & 5.693 & $\mathbf{M}_{\mathbf{3 7}}$ & 2.677 & 2.834 & 8.045 \\
$\mathbf{M}_{\mathbf{1 8}}$ & 3.254 & 4.935 & 2.653 & $\mathbf{M}_{\mathbf{3 8}}$ & 1.12 & 0.912 & 1.341 \\
$\mathbf{M}_{\mathbf{1 9}}$ & 11.52 & 10.08 & 7.267 & $\mathbf{M}_{\mathbf{3 9}}$ & 2.704 & 1.702 & 2.776 \\
$\mathbf{M}_{\mathbf{2 0}}$ & 6.622 & 8.028 & 5.21 & $\mathbf{M}_{\mathbf{4 0}}$ & 8391.73 & 452.938 & 803.707 \\
\hline
\end{tabular}

Source: Calculated from the respective financial statements of the borrowing firms from the records kept with the NBFC

Note: Company Names are kept confidential by the NBFCs request. 
A firm having $\mathrm{z}$ score less than 1 is declared to be in distressed zone. If the $\mathrm{z}$ score is more than 2.9 the firm is in safe zone. A firm remains in the grey zone if the $\mathrm{z}$ score lies between 1.23 to 2.9. Table -1 depicts that six companies will be in the grey zone by the end of the financial year 2017-18. Company ' $\mathrm{M}_{1}$ ' was in distress zone for a period of 2015-16 and 2016-17. Whereas company ' $\mathrm{M}_{18}$ ' was in safe zone for the same period. Company ' $\mathrm{M}_{37}$ ' had overcome the grey zone in the last financial year say 2017-18.

The count of debtor companies according to their solvency status predicted through Altman's Z score model is displayed table-2. It shows that the number of companies in distress status are quite significant.

Table 2. Status of forty corporate borrowers according to Altman Z-score

\begin{tabular}{llll}
\hline Status & $\mathbf{2 0 1 5 - 1 6}$ & $\mathbf{2 0 1 6 - 1 7}$ & $\mathbf{2 0 1 7 - 1 8}$ \\
\hline Safe & 28 & 29 & 28 \\
Grey & 7 & 5 & 7 \\
Distress & 5 & 6 & 5 \\
Total & 40 & 40 & 40
\end{tabular}

Table-3 depicts that ' $\mathrm{M}_{9}$ ', ' $\mathrm{M}_{11}$ ', ' $\mathrm{M}_{14}$ ', ' $\mathrm{M}_{18}$ ', and ' $\mathrm{M}_{34}$ ', are the five companies have been falling in the distress zone continuously in the three financial years. Out of the above mentioned five borrowers, ' $M_{9}$ '. and ' $M_{11}$ ' companies were declared as defaulters by the lending NBFC. It is important to know why the companies default when they are in the distress zone. The odds of default for these companies is also very high as per Altman's Z-Score model. To find out the reasons of the changes in the credit worthiness, we used the DuPont technique, which gives a five-step break of the financial performance of the company, which is generally shown in Return on Equity (ROE).

The return on equity (ROE) values for all the companies including the default companies under study are checked. The ROE of the companies ' $\mathrm{M}_{9}$ '. \& ' $\mathrm{M}_{11}$ ' are found to be negative (Refer to table-3). This indicates that the shareholder of these companies are getting loss from the business operation. The ROE of these companies have been decreasing year after year and leading to financial default.

\subsection{Results of DuPont}

DuPont Corporation (1920) developed DuPont analysis for performance measurement. It is used to assess the company's profitability. This model is also called as "DuPont identity". DuPont analysis depicts that ROE is affected by three things; a) Operating Efficiency, b) Asset Use Efficiency, c) Financial Leverage.

ROE $=($ Net Profit Margin x (Asset Turnover) $\mathrm{x}$ (Equity Multiplier)

Where, Net Profit Margin = Net Income/Sales

Asset Turnover $=$ Sales $/$ Total Assets

Equity Multiplier $=$ Total Assets/Shareholders Equity

ROE $=($ Net Income/Sales $) \times($ Sales/Total Assets) $x($ Total Assets/Shareholders Equity $)$

It is a good sign if there is an increase in ROE due to an increase in net margin or asset turnover. On the contrary, it also suggests that if the equity multiplier affects ROE, then it is a sign to refer or to observe. The five-step DuPont identity is an expansion over the three-steps DuPont identity that breaks down return on equity (ROE) into five parts such as tax burden, interest burden, operating profit margin, total asset turnover and financial leverage. The model also depicts how the interest payments on debt impacts profit margin. To identify the reasons of changes in the credit worthiness, DuPont technique is used. The result of Du Pont shares a five-step break of the financial performance of the company. 
Table 3. Return on Equity for the debtor firms in 2015-16, 2016-17 and 2017-18.

\begin{tabular}{|c|c|c|c|c|c|c|c|}
\hline \multirow{2}{*}{$\begin{array}{l}\text { Company } \\
\text { Name }\end{array}$} & \multicolumn{3}{|l|}{ Year } & \multirow{2}{*}{$\begin{array}{l}\text { Company } \\
\text { Name }\end{array}$} & \multicolumn{3}{|l|}{ Year } \\
\hline & 2015-16 & 2016-17 & 2017-18 & & 2015-16 & 2016-17 & 2017-18 \\
\hline $\mathbf{M}_{1}$ & $46.60 \%$ & $48.63 \%$ & $73.90 \%$ & $\mathrm{M}_{21}$ & $37.28 \%$ & $21.83 \%$ & $15.33 \%$ \\
\hline $\mathbf{M}_{2}$ & $0.34 \%$ & $-7.64 \%$ & $3.74 \%$ & $\mathrm{M}_{22}$ & $15.22 \%$ & $14.72 \%$ & $15.08 \%$ \\
\hline $\mathbf{M}_{3}$ & $25.60 \%$ & $16.02 \%$ & $10.92 \%$ & $\mathrm{M}_{23}$ & $33.54 \%$ & $38.87 \%$ & $31.30 \%$ \\
\hline $\mathbf{M}_{4}$ & $25.40 \%$ & $18.16 \%$ & $15.35 \%$ & $\mathrm{M}_{24}$ & $20.20 \%$ & $11.99 \%$ & $12.98 \%$ \\
\hline $\mathbf{M}_{5}$ & $13.34 \%$ & $4.77 \%$ & $3.99 \%$ & $\mathbf{M}_{25}$ & $2.69 \%$ & $3.41 \%$ & $2.69 \%$ \\
\hline $\mathbf{M}_{6}$ & $11.82 \%$ & $11.87 \%$ & $8.15 \%$ & $\mathrm{M}_{26}$ & $11.46 \%$ & $2.33 \%$ & $0.30 \%$ \\
\hline $\mathbf{M}_{7}$ & $30.09 \%$ & $20.94 \%$ & $14.87 \%$ & $\mathrm{M}_{27}$ & $8.98 \%$ & $8.24 \%$ & $8.31 \%$ \\
\hline $\mathbf{M}_{8}$ & $28.41 \%$ & $35.88 \%$ & $8.08 \%$ & $\mathbf{M}_{28}$ & $12.67 \%$ & $10.18 \%$ & $8.32 \%$ \\
\hline $\mathbf{M}_{9}$ & $-3.03 \%$ & $-0.54 \%$ & $-12.98 \%$ & $\mathbf{M}_{29}$ & $1.09 \%$ & $-27.11 \%$ & $16.13 \%$ \\
\hline $\mathbf{M}_{10}$ & $24.42 \%$ & $3.93 \%$ & $9.71 \%$ & $\mathrm{M}_{30}$ & $0.87 \%$ & $1.02 \%$ & $1.15 \%$ \\
\hline $\mathbf{M}_{11}$ & $-26.66 \%$ & $-150.69 \%$ & $508.71 \%$ & $\mathrm{M}_{31}$ & $16.95 \%$ & $15.60 \%$ & $16.77 \%$ \\
\hline $\mathbf{M}_{12}$ & $0.28 \%$ & $17.87 \%$ & $14.66 \%$ & $\mathrm{M}_{32}$ & $53.17 \%$ & $17.41 \%$ & $10.28 \%$ \\
\hline $\mathbf{M}_{13}$ & $3.85 \%$ & $3.69 \%$ & $4.32 \%$ & $\mathrm{M}_{33}$ & $-1.49 \%$ & $-0.16 \%$ & $1.73 \%$ \\
\hline $\mathbf{M}_{14}$ & $-2.99 \%$ & $-2.78 \%$ & $-1.24 \%$ & $\mathrm{M}_{34}$ & $-0.35 \%$ & $0.27 \%$ & $-0.57 \%$ \\
\hline $\mathbf{M}_{15}$ & $100.32 \%$ & $8.04 \%$ & $3.38 \%$ & $\mathbf{M}_{35}$ & $2.61 \%$ & $0.84 \%$ & $1.17 \%$ \\
\hline $\mathbf{M}_{16}$ & $14.72 \%$ & $18.03 \%$ & $15.85 \%$ & $\mathbf{M}_{36}$ & $1.05 \%$ & $4.36 \%$ & $0.72 \%$ \\
\hline $\mathbf{M}_{17}$ & $26.01 \%$ & $20.99 \%$ & $11.57 \%$ & $\mathrm{M}_{37}$ & $-1.49 \%$ & $-0.16 \%$ & $1.73 \%$ \\
\hline $\mathbf{M}_{18}$ & $0.00 \%$ & $16.40 \%$ & $0.35 \%$ & $\mathbf{M}_{38}$ & $6.28 \%$ & $3.61 \%$ & $5.36 \%$ \\
\hline $\mathbf{M}_{19}$ & $43.99 \%$ & $17.83 \%$ & $25.86 \%$ & $\mathbf{M}_{39}$ & $-0.12 \%$ & $1.31 \%$ & $0.75 \%$ \\
\hline $\mathbf{M}_{20}$ & $7.54 \%$ & $12.14 \%$ & $9.03 \%$ & $\mathrm{M}_{40}$ & $0.00 \%$ & $1.17 \%$ & $2.68 \%$ \\
\hline
\end{tabular}

Source: Calculated from the respective financial statements of the borrowing firms from the records kept with the NBFC

Note: Company Names are kept confidential by the NBFCs request.

It is seen in Table-4 that company 'M9' has no tax burden initially as its revenue is very less in comparison to the operating expenses and so the earnings before interest and tax (EBIT) has come negative. This can be well understood from the operating income margin that had gone negative in the period 2017-18. In the same period as the firm has to meet its debt obligations the EBT (earnings before tax) goes much more negative. So as there, in no taxable, earning of the company, the tax is not to pay. 
Table 4. Financial Information and DuPont of 'M9' (Figures in Indian Rupees)

\begin{tabular}{llll}
\hline Particulars & $\mathbf{2 0 1 5 - 1 6}$ & $\mathbf{2 0 1 6 - 1 7}$ & $\mathbf{2 0 1 7 - 1 8}$ \\
\hline Revenue & 6562711 & 31914975 & 26043551 \\
EBIT & -57861153 & 14275484 & 5766666 \\
EBT & -65827736 & -11769669 & -286440812 \\
Interest Expenses & 7966583 & 26045153 & 292207478 \\
Income Tax & 0 & 0 & -34888991 \\
Net Income & -65827736 & -11769669 & -251551821 \\
Total Assets & 2969832547 & 2960210199 & 4389659699 \\
Share-holders' Equity & 2173251998 & 2162482328 & 1937898191 \\
\hline FIVE - STEP DUPONT ANALYSIS & & \\
\hline Tax Burden & 1 & 1 & 0.88 \\
Interest Burden & 1.14 & -0.82 & -49.67 \\
Operating Income Margin & $-881.67 \%$ & $44.73 \%$ & $22.14 \%$ \\
Asset Turnover & 0 & 0.01 & 0.01 \\
Equity Multiplier & 1.37 & 1.37 & 2.27 \\
Return on Equity & $\mathbf{- 3 . 0 3 \%}$ & $\mathbf{- 0 . 5 4 \%}$ & $\mathbf{- 1 2 . 9 8 \%}$ \\
\hline
\end{tabular}

Source: Calculated from the respective financial statements of the borrowing firms from the records kept with the NBFC

Table- 4 shows that the net income of the company is deteriorating gradually. Thus, the shareholders' equity is also falling year after year due to negative reserves and surplus generated by the company. The ROE has reached to its maximum negative value of almost $13 \%$ in the year 2017-18 and the company could not repay the debt. Five step DuPont table along with the key financial information for the defaulted company, ' $\mathrm{M}_{11}$ ' is given below.

Table 5. Financial Information and DuPont of 'M11' (Figures in Indian Rupees)

\begin{tabular}{llll}
\hline & $\mathbf{2 0 1 5 - 1 6}$ & $\mathbf{2 0 1 6 - 1 7}$ & $\mathbf{2 0 1 7 - 1 8}$ \\
\hline Revenue & 3607927000 & 376949000 & 56870000 \\
EBIT & 46735000 & -200551000 & -341119000 \\
EBT & -186008000 & -431322000 & -345470000 \\
Interest Expenses & 232743000 & 230771000 & 4351000 \\
Income Tax & 158000 & 12242000 & 682000 \\
Net Income & -185850000 & -419080000 & -346152000 \\
Total Assets & 2806497000 & 2482269000 & 2015503000 \\
Shareholders' Equity & 697187000 & 278107000 & -68045000 \\
\hline FIVE STEP DUPONT ANALYSIS & & & \\
\hline Tax Burden & 0.999 & 0.972 & 1.002 \\
Interest Burden & -3.980 & 2.151 & 1.013 \\
Operating Income Margin & $1.30 \%$ & $-53.20 \%$ & $-599.82 \%$ \\
Asset Turnover & 1.286 & 0.152 & 0.028 \\
Equity Multiplier & 4.025 & 8.926 & -29.620 \\
Return on Equity & $\mathbf{- 2 7 \%}$ & $\mathbf{- 1 5 1 \%}$ & $\mathbf{5 0 9 \%}$ \\
\hline
\end{tabular}

Source: Calculated from the respective financial statements of the borrowing firms from the records kept with the NBFC 
It is seen in Table-5 that the ROE is negative for 2015-16 and 2016-17. For the financial year 2017-18, the ROE is $509 \%$, which is very high. This is an exceptional case. It is because ROE is the ratio of net income and the shareholder's equity and both the values in the numerator and denominator of the ratio are negative. Thus, the resultant ratio for the year 2017-18 appears as positive. With an illusion, the ROE of ' $\mathrm{M}_{11}$ ' ' is negative for the year 2017-18. This is a special case as the shareholder's equity is negative with negative reserves and surplus accumulated year on year. Though the magnitude of the negative reserves and surplus is higher than that of the positive share capital, the shareholders' equity has found to be negative. For this company the net income is found to be negative as the interest burden of this company is high. Moreover, the asset turnover ratio is also very low. All of these together lead a negative ROE value that in turn compels the firm to default the debt.

\section{Summary and Conclusion}

The focus of this research paper is to check the financial solvency of the borrowers' companies using Z-score model and to ascertain the credit worthiness of the borrowers' for the next two years. It also assesses the financial distress of the firms. The Z-score model predicted that the borrowing companies with a lower ROE are expected to be in distress zone. In the case of ' $\mathrm{M}_{11}$ ' and ' $\mathrm{M}_{9}$ ' it is seen that both the company's asset turnover ratio is very low which shows inefficiency in asset utilization by the two companies leading towards the distress zone. Thus, the management must take care of the issue. In specific, the revenue generation is very low which may be due to poor marketing and promotion of the product or may be due to the product's cheap quality, which did not attract the customer to spend on it. Interest burden in case of ' $\mathrm{M}_{11}$ ' is initially very high because the debt component is at a higher side and thus the operating income margin reduces gradually bringing down the ROE as a whole.

The model thus depicts that Z-Score model and DuPont identity should be used by the financing organizations before granting loan to the corporates. It may reduce the odds of getting probable default borrower to the Banks and NBFCs. In this research paper for using Altman's Z score, the required financial ratios have been considered. However, other pre-defined models and financial ratios are future scope of research.

\section{Implication of the Study}

This research is very useful for the financial institutes. Our study highlights some of the key characteristics and determinants of defaulter for NBFC sector and these determinants would help the financial institutes to categorize clients in three segments say, safe, grey and distressed. This research would also help the NBFC sector to identify the most likely defaulters and act accordingly in a way to get back the money lent. The research outcome shows the relevance of Altman's Z- score model in the credit risk management decision, which would help the financial institutions like banks and NBFCs to reduce the NPA, which indirectly benefit the society and the taxpayers.

\section{References}

Altman, E.I. (1968). Financial Ratios, Discriminant Analysis and the Prediction of Corporate Bankruptcy. Journal of Finance, 23, 189-209. https://doi.org/10.2307/2978933

Altman, E. (1995). Z Scores - A Guide to Failure Prediction. The CPA Journal, 65(2).

Altman, E. I. (1993). Corporate Financial Distress and Bankruptcy: A Complete Guide to Predicting and Avoiding Distress and Profiting from Bankruptcy. 2nd Ed. New York: John Wiley and Sons.

Altman, Edward I. (July 2000). Predicting Financial Distress of Companies. Retrieved on September 4th, 2009 from http://pages.stern.nyu.edu/ ealtman/Zscores.pdf: 15-22.

Altman, Edward I. (May 2002). Revisiting Credit Scoring Models in a Basel II Environment. Prepared for "Credit Rating: Methodologies, Rationale, and Default Risk. London Risk Books 2002.

Altman, E.I., Marco, G., Varetto, F. (1994). Corporate Distress Diagnosis: Comparison Using Linear Discriminant Analysis and Neural Networks (The Italian Experience). Journal of Banking and Finance, 18, 505-529. https://doi.org/10.1016/0378-4266(94)90007-8

Bardos,M. (1998). Detecting the risk of company failure at the Banque de France. Journal of Banking \&Finance, 2(10-11), 1405-1419. https://doi.org/10.1016/S0378-4266(98)00062-4

Basak Suleyman \& Shapiro Alex. (2004). A model of credit risk, optimal policies and asset prices. Journal of business.

Bensic, M., Sarlija, N., Zekic-Susac, M. (2005). Modelling small-business credit scoring by using logistic regression, neural networks and decision trees. Intelligent Systems in Accounting, Finance and Management, 13(3), 133-150. https://doi.org/10.1002/isaf.261 
Ciampi, F., Gordini, N. (2008). Using Economic-Financial Ratios for Small Enterprise Default Prediction Modelling: An Empirical Analysis. Oxford Business \& Economics Conference Program, Oxford University, UK, 1-21.

Desai, V.S., Conway, D.G., Crook, J.N., Overstreet, G.A. (1997). Credit Scoring Models in Credit Union Environment Using Neural Network and Generic Algorithms. IMA Journal of Mathematics Applied in Business \& Industry, 8, 323-346. https://doi.org/10.1093/imaman/8.4.323

Eidleman, Gregory J. (1995). Z-Scores - A Guide to Failure Prediction. The CPA Journal Online.

Greene, W. (1998). Sample Selection in Credit-Scoring Models. Japan and the World Economy, 10(3), 299-316. https://doi.org/10.1016/S0922-1425(98)00030-9

Gumparthi Srinivas, Khatri Swetha, Manickavasagam V. (2011). Design and development of credit risk rating model for public sector banks in India: special reference to small and medium enterprises. Journal of Accounting and taxation, 3(5), 105-124.

Kay Giesecke. (2004). credit risk modelling and valuation: An introduction. Credit Risk: Models and Management, 2. https://doi.org/10.2139/ssrn.479323

Kumar M.N \& Hari Rao V.Sree. (2014). a new methodology for estimating internal credit risk and bankruptcy prediction under BaselII regime. Computational Economics. https://doi.org/10.1007/810614-014-9459-9

Lim, M. K., Sohn, S. Y. (2007). Cluster-Based Dynamic Scoring Model. Expert Systems with Applications, 32(2): 427-431. https://doi.org/10.1016/j.eswa.2005.12.006

Min, J. H., Lee, Y-C. (2008). A practical approach to credit scoring. Expert Systems with Applications, 35(4), 1762-1770. https://doi.org/10.1016/j.eswa.2007.08.070

Mall,S. (2018). An empirical study on credit risk management: The case of non-banking financial companies. Journal of credit risk, 14(3), 49-66. https://doi.org/10.21314/JCR.2017.239

Min, J. H., Jeong, C. (2009). A binary classification method for bankruptcy prediction. Expert Systems with Applications, 36(3), 5256-5263. https://doi.org/10.1016/j.eswa.2008.06.073

Lee, T. C., I. Chen. (2005). A Two-Stage Hybrid Credit Scoring Model Using Artificial Neural Networks and Multivariate Adaptive Regression Splines. Expert Systems with Applications, 28, 743-752. https://doi.org/10.1016/j.eswa.2004.12.031

Ong, C., Huang, J., Tzeng, G. (2005). Building Credit Scoring Models Using Genetic Programming. Expert Systems with Applications, 29(1), 41-47. https://doi.org/10.1016/j.eswa.2005.01.003

RBI Bulletin: https://www.rbi.org.in

Steenackers, A., \& Goovaerts, M. J. (1989). A Credit Scoring Model for Personal Loans. Insurance: Mathematics and Economics, 8, 31-34. https://doi.org/10.1016/0167-6687(89)90044-9

Thomas Lyn C. (2000). A survey of credit and behavioural scoring : Forecasting financial risk of lending to $\begin{array}{lllll}\text { consumers. International journal of forecasting, } & 16(2000), & \text { 149-172. }\end{array}$ https://doi.org/10.1016/S0169-2070(00)00034-0

Thomas, L. C., Edelman, D. B., \& Crook, L. N. (2002). Credit Scoring and its Applications. Philadelphia: Society for Industrial and Applied Mathematics. https://doi.org/10.1137/1.9780898718317

\section{Note}

Note 1. (RBI website: https://www.rbi.org.in) 